\title{
Isolation, characterization, and functional groups analysis of Pseudoxanthomonas indica RSA-23 from rhizosphere soil
}

Sreenivasa Nayaka*, Bidhayak Chakraborty, Pallavi Sathyanarayan Swamy, Meghashyama Prabhakara Bhat, Dattatraya Airodagi, Dhanyakumara Shivapoojar Basavarajappa, Muthuraj Rudrappa, Halaswamy Hiremath, Shashiraj Kareyelloppa Nagaraja, Chaitra Madhappa

P.G. Department of Studies in Botany, Karnatak University, Dharwad, Karnataka, India.

\begin{tabular}{|c|c|}
\hline ARTICLE INFO & ABSTRACT \\
\hline Received on: 11/07/2019 & \multirow{4}{*}{$\begin{array}{l}\text { In the present study, Pseudoxanthomonas species were isolated from rhizosphere soil samples of two selected medicinal } \\
\text { plants, such as Alternenthera sessilis Linn. and Leucas aspera (Wild) Linn., which were collected from agricultural } \\
\text { fields at Kundagol, Dharwad, Karnataka. Pseudoxanthomonas sp. is Gram negative, aerobic, motile, non-spore forming } \\
\text { rod shaped bacterium and it was designated as Pseudoxanthomonas strain RSA-23; it was found to possess broad } \\
\text { spectrum of antimicrobial activity against pathogenic microorganisms. Furthermore, the most potent strain RSA-23 } \\
\text { was characterized by physiological, biochemical, and } 16 \mathrm{~S} \text { ribosomal RNA gene sequencing. The } 16 \mathrm{~S} \text { ribosomal RNA } \\
\text { gene sequencing and analysis of phylogenetic tree showed } 100 \% \text { sequence similarity with Pseudoxanthomonas indica } \\
\text { (KT204489). The methanol extract of Pseudoxanthomonas strain RSA-23 was analyzed through UV-spectroscopy and } \\
\text { Fourier transform infrared spectroscopy (FTIR). The UV-Vis. spectra revealed the presence of indole and the presence } \\
\text { of different functional groups, such as aldehydes, amines, and alkyl halides, were indicated by FTIR spectra. }\end{array}$} \\
\hline Accepted on: 22/08/2019 & \\
\hline Available online: $04 / 11 / 2019$ & \\
\hline $\begin{array}{l}\text { Key words: } \\
\text { Pseudoxanthomonas sp, } \\
\text { rhizosphere soil, antimicrobial } \\
\text { activity, FTIR, 16S rRNA } \\
\text { gene sequencing. }\end{array}$ & \\
\hline
\end{tabular}

\section{INTRODUCTION}

Rhizosphere is the portion of soil which surrounds a living root. The rhizosphere soil is different from the soil away from the root zone in terms of chemical and physical nature and is always influenced by organic and inorganic exudates from the roots which affect the inhabited microbial communities surrounding it (Kent and Triplett, 2002). The rhizosphere contains both beneficial and harmful pathogenic microorganisms. The microorganisms residing in rhizosphere area are mycorrhizal fungi, nitrogen fixing bacteria, plant growth promoting rhizobacteria (PGPR), protozoa, actinomycetes, and harmful microorganisms which includes oomycetes, pathogenic bacteria, nematodes, and other human pathogenic microbes (Kaestli et al., 2011; Teplitski et al., 2012).

"Corresponding Author

Sreenivasa Nayaka, P.G. Department of Studies in Botany, Karnatak University, Dharwad, Karnataka, India.

E-mail: sreenivasankud@gmail.com
There are obvious differences between the rhizosphere and non-rhizosphere soils of the plants. The microbial association of rhizosphere soil is always higher than non-rhizosphere soil. The rhizosphere soil of medicinal plants has a structurally and functionally distinct microbial community and this distinct microbiota is due to the secretion of unique bioactive secondary metabolites. These unique secondary metabolites may be responsible for diverse microbial association. The plant Leucas aspera (Wild) Linn. is a member of the family Lamiaceae. The plant is an annual herb with quadrangular stem, the leaves are sessile, and flowers are white in color (Hooker, 1984). The plant has antimicrobial, antifungal, cytotoxic, and antioxidant properties (Mangathayaru, 2005). The plant Leucas aspera (Wild) Linn. was traditionally being used as antipyretic and insecticides, the leaves were used in chronic skin eruptions and snake bite (Rai et al., 2005). Alternenthera sessilis Linn. is a leafy vegetable, generally found near tropical and sub-tropical areas. The plant is herbaceous with annual or perennial nature. The plant has antibacterial, cytotoxic, and anti-allergic properties (Ullah et al., 2013).

The study of bacteria inhabitant of rhizosphere soil is important because of their effect on plant growth, production of 
industrially and medicinally useful metabolites (Rayees et al., 2013). The yield and quantity of compounds of medicinal plants, nutrient uptake, and disease resistance are largely influenced by rhizosphere microorganisms (Bafana and Lohiya, 2013). In plant rhizosphere region, aerobic, gram positive, and sporulating bacteria are less as compared to anaerobic, Gram negative, and non-sporulating bacteria (Zakaria and Anawar, 2014) having a great symbiotic association to plants. These microorganisms take the exudates of plants as food, plants also takes some organic elements from the microorganisms for avoiding their nutrient deficiency for better growth and development.

The Pseudoxanthomonas is Gram negative, aerobic, atrichous, rod shaped, and non-spore forming bacteria which was first reported by Finkmann from experimental biofilters (Merckx et al., 1987). Taxonomically, the genus Pseudoxanthomonas belongs to the phylum Proteobacteria class Gammaproteobacteria and family Xanthomonadaceae (Finkmann et al., 2000). This genus is phylogenetically related to the genera Xanthomonas, Xylella, and Stenotrophomonas. Members of this genus have iso $\mathrm{C}_{15: 0}$ and anteiso $\mathrm{C}_{15: 0}$ as major fatty acids and ubiquinone (Q8) as major respiratory quinine (Soo et al., 2015). Ecologically, the genus Pseudoxanthomonas is important due to the ability to degrade nitrate, nitrite, and different hydrocarbons, including ethyl-benzene, toluene, and benzene (Thierry et al., 2004). In addition to this, Pseudoxanthomonas has various other applications in science in being used in the field of medical science, pharmaceutical science, food science, bioremediation, biodegradation and in agricultural field like PGPR for growth and development of plants without any use of chemical fertilizers. The present study aims to isolate Pseudoxanthomonas sp. from two medicinal plants to elucidate their antimicrobial activity against various pathogenic bacteria and fungi and the molecular characterization of the potent isolate using $16 \mathrm{~S}$ rRNA gene sequencing.

\section{MATERIALS AND METHODS}

\section{Collection and processing of sample}

Around $500 \mathrm{~g}$ of soil samples were collected in sterile polythene bags from rhizosphere of two medicinal plants, namely, $A$. sessilis Linn. and L. aspera (Wild) Linn. from agricultural fields of Gudgeri, Kundagol, Dharwad. The soil samples were then labeled and air-dried at room temperature for 3 to 4 days. The cleaned and air dried samples were refilled in the respective polythene bags and stored at $4{ }^{\circ} \mathrm{C}$ for further studies (Fatima et al., 2017).

\section{Isolation of microorganisms}

Each soil sample was serially diluted and $100 \mu \mathrm{l}$ of aliquots from $10^{-1}, 10^{-2}, 10^{-3}, 10^{-4}, 10^{-5}$, and $10^{-6}$ were spread evenly on nutrient agar (NA); $\mathrm{pH} 7.0$ and czapek dox agar media aseptically. Both the media were supplemented with antibiotics and antifungal, such as Amphotericin B-50 and Tetracyclin (25 $\mu \mathrm{g} / \mathrm{ml}$ each), to inhibit the growth of unwanted bacteria and fungi. The plates were incubated at $30^{\circ} \mathrm{C}$ for 3 days and observed periodically for the growth of microbial strains and maintained in nutrient agar slants at $4{ }^{\circ} \mathrm{C}$ for subsequent studies (Fatima et al., 2017).

\section{Primary screening for antimicrobial activities}

During the primary screening, the isolates were screened against pathogenic bacterial strains by perpendicular streak (cross streak) method according to Saravanakumar et al. (2014). In this method, nutrient agar medium was used and each plate was streaked with individual isolates along the diameter of the plate and incubated at $30^{\circ} \mathrm{C}$ for 4 days. Later, 24 hour fresh sub-cultured fungi and bacteria, viz., Aspergillus fumigatus (MTCC8877), Enterobacter aerogenes (ATTC2822), Staphylococcus epidermidis (MTCC435), and Shigella flexneri (MTCC1457) were prepared and streaked perpendicular to the isolates and incubated at $37^{\circ} \mathrm{C}$ for 48 hours.

\section{Morphological, physiological, and biochemical characterization}

Morphological and physiological characterization was done by checking the growth in the range of temperature from $20^{\circ} \mathrm{C}$ to $40^{\circ} \mathrm{C}$ and at different $\mathrm{pH}$ level from $\mathrm{pH} 6.0$ to $\mathrm{pH} 8.0$. The biochemical analysis of hydrolysis tests were conducted on R2A medium supplemented with starch $(1 \% \mathrm{w} / \mathrm{v})$, casein $(5 \%$ $\mathrm{w} / \mathrm{v})$, urea, and gelatin. Oxidase and catalase activity were tested and tests for the utilization of carbon sources such as D-glucose, maltose, D-mannose, L-arabinose, D-galactose, and citrate were done according to Yoo et al. (2007).

\section{DNA extraction and 16S rRNA gene sequencing}

The genomic DNA was extracted from the fresh culture of the potent isolate. The 16SrRNAgenes were amplified using primers. The forward primer 5'-AGAGTTTGATCMTGGCTCAG-3' (400 $\mathrm{ng}$ ) and $16 \mathrm{~S}$ reverse primer 5'-TACGGYTACCTTGTTACGACTT$3^{\prime}$ (400 ng). The following condition were used for the PCR amplification; initial denaturation of 25 cycles at $96^{\circ} \mathrm{C}$ for 5 minutes, denaturation at $96^{\circ} \mathrm{C}$ for 1 minutes, hybridization at $50^{\circ} \mathrm{C}$ for 1 minutes, and elongation (final extension) $60^{\circ} \mathrm{C}$ for 2 minutes as described by Yoon et al. (1998). The PCR products were electrophoresed on $1 \%$ agarose gel with $500 \mathrm{bp}$ DNA ladder as the size reference. Purified PCR amplicons were sequenced (sequence machine, Applied Biosystems, Sanger Sequencing 3500 Series, Genetic Analyzer) and used to interrogate the National Centre for Biotechnology Information (NCBI) database via BLASTN web portal according to Saravanakumar et al. (2014). The DNA sequences were aligned and a phylogenetic tree was constructed by the neighbor joining method using the software MEGA 7.0 by the method of Kumar et al. (2016).

\section{Fermentation and extraction of bioactive compound}

The isolated strain was grown in nutrient broth $(\mathrm{pH} 7.0)$ and incubated at $30^{\circ} \mathrm{C}$ in a rotary shaker. After fermentation, the biomass was centrifuged at 5,000 rpm for 20 minutes and washed three times with sterile distilled water. The intra-cellular bioactive compounds were then extracted through solid-liquid extraction method. The biomass was suspended in a little amount of methanol and ground with a pestle and mortar. Methanol was added to the ground cells $(1: 1 \mathrm{w} / \mathrm{v})$ and the mixture was shaken vigorously overnight. The extract was then filtered through a blotting paper and the filtrate was evaporated using a rotary evaporator at $50^{\circ} \mathrm{C}$. The concentrated extract was then transferred into glass screw cap tubes and storage was done at $4^{\circ} \mathrm{C}$ for further 
use (Saravanakumar et al., 2014). Later, the crude extract was subjected to silica gel column chromatography and eluted with mixtures of $\mathrm{CHCl}_{3}: \mathrm{CH}_{3} \mathrm{OH}$ (Chloroform:Methanol).

\section{Ultraviolet visible (UV-Vis) spectroscopy}

The qualitative analysis of the crude methanol extract was performed by UV-visible spectroscopy for the probable determination of natural compounds using a Jasco V-670 UV/VIS spectrophotometer.

\section{Fourier transform infrared resonance (FT-IR) spectral analysis}

The biological functional groups present in the methanol extract was interpreted by FT-IR spectroscopy, using $\mathrm{KBr}$; mixed with extract and compressed to make thin discs to be analyzed in prominent infrared resonance spectra in the range of 400 to $4,000 \mathrm{~cm}^{-1}$. The Fourier transform infrared (FTIR) spectrum of active extract was detected using Nicolet 6700 (Thermo scientific Class 1 Laser product-APW 1300066) in University Scientific and Instruments Centre (USIC), Karnatak University, Dharwad.

\section{RESULTS AND DISCUSSION}

Totally, 47 microorganisms were isolated from rhizosphere soils on NA. Among them, only the colonies showing yellow color with circular and entire margins were sub-cultured. Different studies showed the isolation of various species of Pseudoxanthomonas from different samples such as bio-filters (Finkmann et al., 2000), sludge, soil (Thierry et al., 2004), and compost (Weon et al., 2006). Among all the isolates, only 25 isolates were found to be Gram-negative strains and the strain RSA-23 showed 100\% inhibition for all the pathogenic organisms during primary screening (Fig. 1), this was used for further analysis. Rest all organisms showed moderate inhibition against the pathogenic organisms (Table 1).

\section{Morphological, physiological, and biochemical characterization}

The detailed morphological, physiological, and biochemical properties of the strain RSA-23 was shown in the Table 2. The $\mathrm{pH}$ which favored optimum growth of the strain RSA-23 was found at $\mathrm{pH}$ 7.0. But, there was no positive effect on
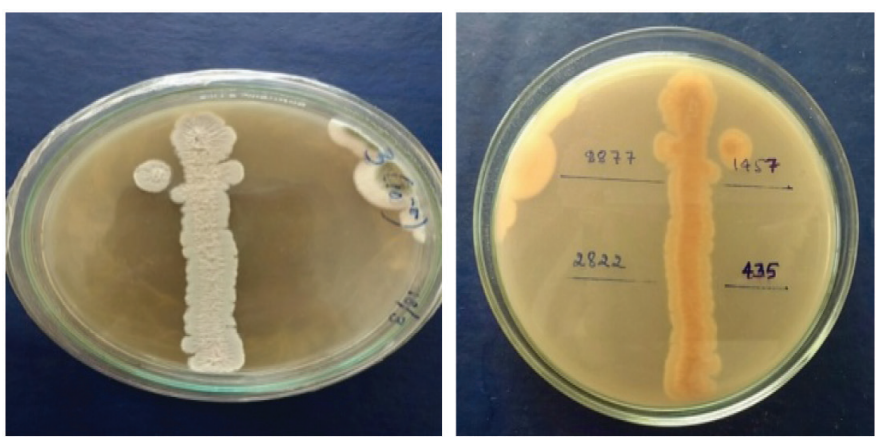

Figure 1. Primary screening of strain RSA-23 using cross streak method against A. fumigatus (MTCC8877), S. flexneri (MTCC1457), E. aerogenes(ATTC2822), and S. epidermidis (MTCC435). growth at the $\mathrm{pH}$ below and above 7.0. The effect of temperature on the strain RSA-23 showed a relatively good growth at $30^{\circ} \mathrm{C}$. Our results were confirmative with the result of Jianli et al. (2014), where Pseudoxanthomonas wuyuanensis showed optimum growth at $30^{\circ} \mathrm{C}$ to $37^{\circ} \mathrm{C}$ at $\mathrm{pH} 6.0$ to 7.0 . The strain $\mathrm{RSA}-23$ showed the positive test for starch and aesculin, whereas casein, gelatin, and urea were negative. The carbon sources most utilized by the strain RSA-23 were D-glucose, maltose, and D-mannose. There was no growth observed in L-arabinose and D-galactose. The organism was found positive for oxidase and catalase. A similar result was found by Soo et al. (2015) for Pseudoxanthomonas sangjuensis isolated from greenhouse soil.

\section{$16 \mathrm{~S}$ ribosomal RNA gene sequencing}

The genomic DNA was isolated from the strain RSA-23 and analyzed by $16 \mathrm{~S}$ rRNA gene sequencing with the help of PCR amplification. 16S rRNA is a small segment of RNA which is associated with $30 \mathrm{~S}$ small subunit of bacterial ribosome and has a wide use in identification of microorganisms up to species level. The complete sequence obtained was 1,383 base pair in length. The sequence was submitted to NCBI with the accession number MK905527, which was later, subjected to search of close relatives through Nucleotide BLAST (BLASTN) in NCBI. The analysis of

Table 1. Activity of isolated strains against different test pathogens.

\begin{tabular}{|c|c|c|c|c|}
\hline Strain No. & $\begin{array}{l}\text { A. fumigatus } \\
\text { (MTCC8877) }\end{array}$ & $\begin{array}{l}\text { E. aerogenes } \\
\text { (ATTC2822) }\end{array}$ & $\begin{array}{l}\text { S. epidermidis } \\
\text { (MTCC435) }\end{array}$ & $\begin{array}{c}\text { S. flexneri } \\
\text { (MTCC1457) }\end{array}$ \\
\hline RSA-1 & - & ++ & ++ & - \\
\hline RSA-2 & - & - & - & + \\
\hline RSA-3 & - & - & - & - \\
\hline RSA-4 & - & - & + & + \\
\hline RSA-5 & + & - & - & - \\
\hline RSA-6 & - & - & - & - \\
\hline RSA-7 & + & - & - & + \\
\hline RSA-8 & + & - & ++ & - \\
\hline RSA-9 & - & ++ & + & - \\
\hline RSA-10 & + & - & - & - \\
\hline RSA-11 & - & - & - & - \\
\hline RSA-12 & + & - & ++ & - \\
\hline RSA-13 & - & - & - & - \\
\hline RSA-14 & - & + & - & - \\
\hline RSA-15 & - & - & - & - \\
\hline RSA-16 & + & + & ++ & - \\
\hline RSA-17 & - & + & - & + \\
\hline RSA-18 & - & - & - & \\
\hline RSA-19 & + & - & ++ & - \\
\hline RSA-20 & - & - & - & - \\
\hline RSA-21 & ++ & - & - & + \\
\hline RSA-22 & - & - & - & ++ \\
\hline RSA-23 & ++ & ++ & ++ & ++ \\
\hline RSA-24 & - & - & - & + \\
\hline RSA-25 & ++ & - & - & - \\
\hline
\end{tabular}

(++ Good antimicrobial activity; + Moderate antimicrobial activity; - No antimicrobial activity). 
Table 2. Morphological, physiological and biochemical characterization of strain RSA-23.

\begin{tabular}{|c|c|}
\hline \multicolumn{2}{|c|}{ Characteristics of strainRSA-23 } \\
\hline Habitat & Soil \\
\hline Colony appearance & $\begin{array}{c}\text { Yellow and circular colonies with } \\
\text { entire margin }\end{array}$ \\
\hline Motility & Motile \\
\hline Gram staining & Gram negative \\
\hline $\mathrm{pH}$ & Growth of RSA-23 \\
\hline $\mathrm{pH} 6.0$ & - \\
\hline pH 6.5 & + \\
\hline pH 7.0 & ++ \\
\hline $\mathrm{pH} 7.5$ & $\mathrm{~W}$ \\
\hline $\mathrm{pH} 8.0$ & - \\
\hline \multicolumn{2}{|c|}{ Growth at different temperature $\left({ }^{\circ} \mathrm{C}\right)$} \\
\hline Temperature & Growth of RSA-23 \\
\hline $20^{\circ} \mathrm{C}$ & - \\
\hline $25^{\circ} \mathrm{C}$ & $\mathrm{W}$ \\
\hline $30^{\circ} \mathrm{C}$ & ++ \\
\hline $35^{\circ} \mathrm{C}$ & W \\
\hline $40^{\circ} \mathrm{C}$ & - \\
\hline \multicolumn{2}{|c|}{ Biochemical tests for strain RSA-23 } \\
\hline Starch & + \\
\hline Casein & - \\
\hline Urea & - \\
\hline Gelatin & - \\
\hline Aesculin & + \\
\hline \multicolumn{2}{|c|}{ Assimilation of carbohydrates } \\
\hline D-Glucose & + \\
\hline Maltose & + \\
\hline D-Mannose & + \\
\hline L-Arabinose & - \\
\hline D-Galactose & - \\
\hline Citrate & - \\
\hline Oxidase & + \\
\hline Catalase & + \\
\hline
\end{tabular}

(- No growth; $\mathrm{W}=$ Weak growth, +: Normal growth; ++: Optimum growth).
$16 \mathrm{~S}$ rRNA gene sequence of the strain RSA-23 revealed $100 \%$ sequence similarity with Pseudoxanthomonas indica strain SMV237 (KT204489) and 99.35\% sequence similarity with Pseudoxanthomonas sp. (LC481374), Pseudoxanthomonas sp. strain WP66 (MK720827), Pseudoxanthomonas japonensis strain AF59 (LC015564). Further a phylogenetic tree was constructed through neighbor joining method with obtained gene sequences, the analysis of phylogenetic tree revealed the strain RSA-23 fell within the cluster of the genus Pseudoxanthomonas and formed a branch with $P$. indica SMV237 (KT204489) (Fig. 2). This result can be correlated with the results of Mohapatra et al. (2018), where the strain KAs $5-3^{\mathrm{T}}$ gave the highest sequence similarity (99.25\%) with the members of the genus Pseudoxanthomonas mexicana (AMX 26B ${ }^{\mathrm{T}}$ ).

\section{UV absorption analysis of RSA-23 methanol extract}

The UV-visible spectroscopy was used for quantitative analysis. Generally, the aromatic compounds are powerful chromophores in the UV range; the natural compounds can also be determined by using UV-visible spectroscopy (Kemp, 1991). The methanol extract of the $P$. indica $\mathrm{RSA}-23$ exhibited maximum UV absorption at $263 \mathrm{~nm}$ and $288 \mathrm{~nm}$ as shown in Figure 3. The peaks at $263 \mathrm{~nm}$ and $288 \mathrm{~nm}$ can be attributed to an aromatic heterocyclic compound indole (Kemp, 1991a; 1991b). Indole can be produced by a variety of bacteria and works as an intercellular signal molecule in performing various aspects of bacterial physiology, including plasmid stability and virulence (Lee and Lee, 2010).

\section{FTIR analysis of RSA-23 methanol extract}

The FTIR spectrum of $P$. indica RSA-23 methanol extract used to determine the functional groups by active components, based on the peak values in the region of infrared radiation as shown in the Figure 4 and Table 3. It revealed the presence of different functional groups based on the absorption peaks at 619 and $723 \mathrm{~cm}^{-1}$ due to $\mathrm{C}$-Br stretching alkyl groups and $\mathrm{C}-\mathrm{Cl}$ stretch alkyl halides, respectively, $1,035 \mathrm{~cm}^{-1} \mathrm{C}-\mathrm{N}$ stretch alkyl halides, $1,115 \mathrm{~cm}^{-1} \mathrm{C}-\mathrm{O}$ stretch carboxylic acids/esters, ethers, 1,384 $\mathrm{cm}^{-1} \mathrm{C}-\mathrm{H}$ rock alkanes $/ \mathrm{CH}_{2}$ wag modes, $1,409 \mathrm{~cm}^{-1} \mathrm{C}-\mathrm{C}$ stretch aromatics, $1,462 \mathrm{~cm}^{-1} \mathrm{C}-\mathrm{H}$ bend alkanes, $1,627 \mathrm{~cm}^{-1} \mathrm{~N}-\mathrm{H}$ bend $1^{0}$ amine, $1,739 \mathrm{~cm}^{-1} \mathrm{C}=\mathrm{O}$ stretch esters or saturated aliphatics, 2,854 $\mathrm{cm}^{-1} \mathrm{C}-\mathrm{H}$ stretch alkanes, $2,924 \mathrm{~cm}^{-1} \mathrm{H}-\mathrm{C}=\mathrm{O}$ : C-H stretch

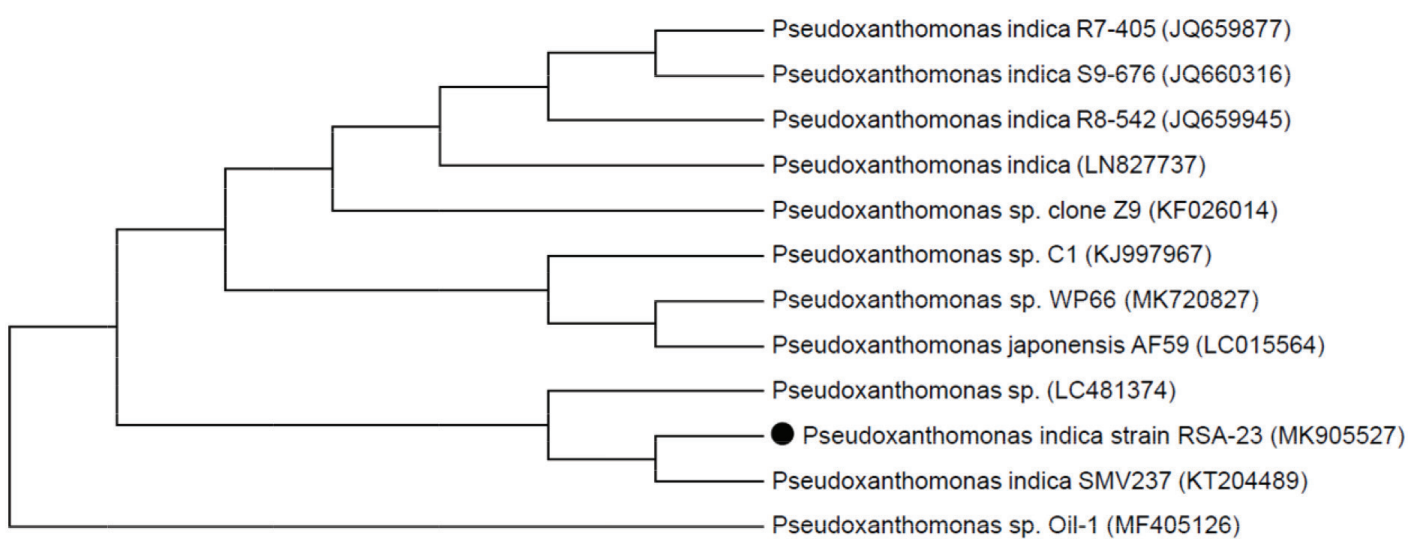

Figure 2. Dendogram indicating the phylogenetic relation of the Pseudoxanthomonas indica RSA-23. 


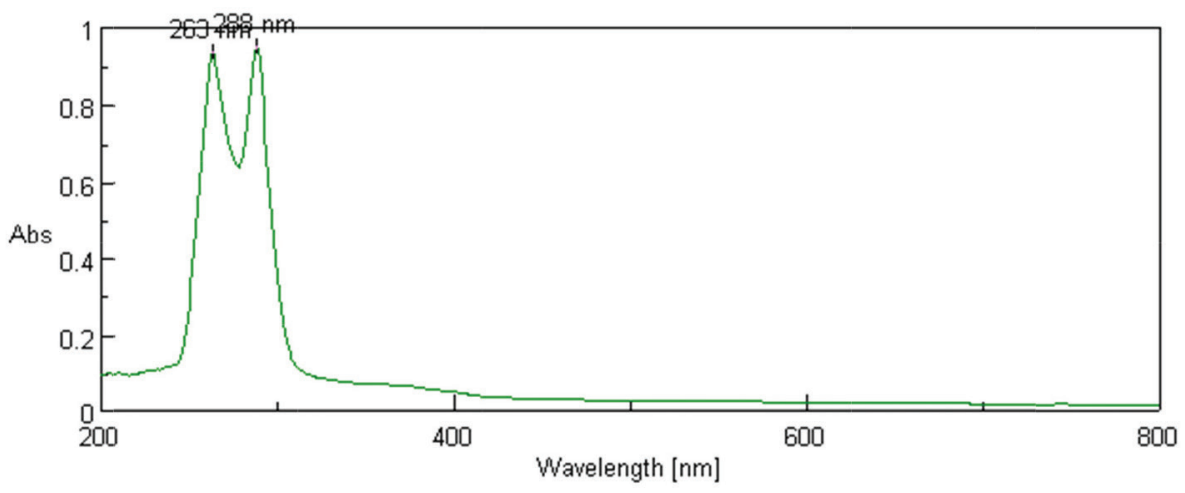

Figure 3. UV-Spectrum of methanol extract of Pseudoxanthomonas indica. RSA-23.

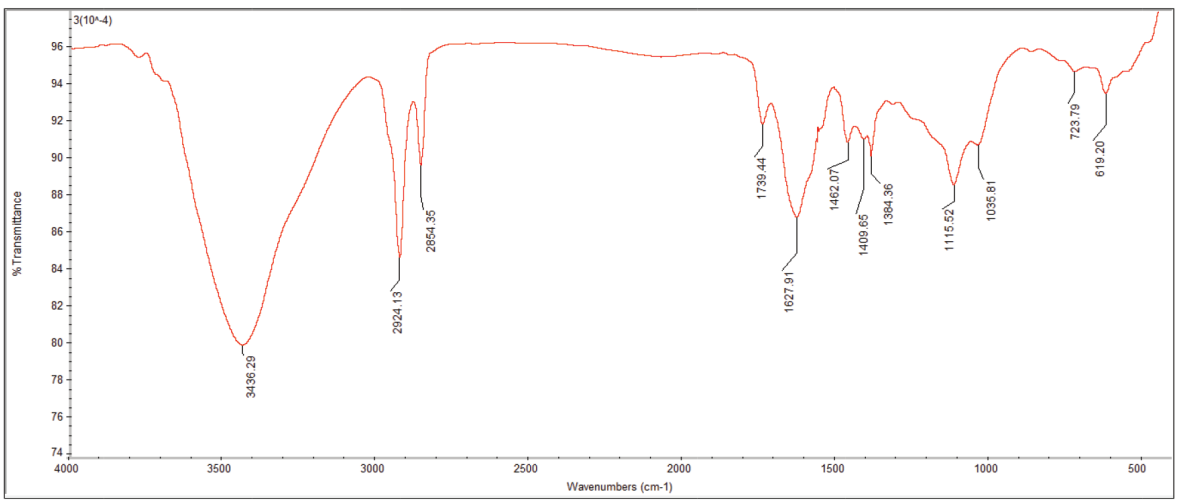

Figure 4. FTIR spectrum of methanol extract of Pseudoxanthomonas indica. RSA-23.

Table 3. FTIR absorption peaks and their associated functional groups.

\begin{tabular}{ccl}
\hline Sl. no. & Absorption peak $\left(\mathbf{c m}^{-1}\right)$ & Functional groups \\
\hline 1 & 619 & C-Br stretching alkyl groups \\
2 & 723 & C-Cl stretch alkyl halides \\
3 & 1,035 & C-N stretch alkyl halides \\
4 & 1,115 & C-O stretch carboxylic acids/esters ethers \\
5 & 1,384 & C-H rock alkanes/ $\mathrm{CH}_{2}$ wag modes \\
6 & 1,409 & C-C stretch aromatics \\
7 & 1,462 & C-H bend alkanes \\
8 & 1,627 & N-H bend $1^{0}$ amine \\
9 & 1,739 & C=O stretch esters, saturated aliphatics \\
10 & 2,854 & C-H stretch alkanes \\
11 & 2,924 & H-C=O: C-H stretch aldehydes \\
12 & 3,436 & O-H stretch alcohols \\
\hline
\end{tabular}

aldehydes, and 3,436 $\mathrm{cm}^{-1} \mathrm{O}-\mathrm{H}$ stretch alcohols. This result was compared with the similar results of Fatima et al. (2017).

\section{CONCLUSION}

The current study shows that the isolated strain $P$. indica RSA-23 from rhizosphere soil samples of agricultural field of Kundagol region has the potential to act against pathogenic microorganisms. Here, we found that agricultural field of Gudgeri, Kundagol, Dharwad (District) is a good region of biodiversity and has been adequately acceptable due to its vast floral and microbial diversity. Results show that the strain $P$. indica $\mathrm{RSA}-23$ is dominant against all the active test pathogens. Thus, the study on this isolate can further be explored for the development of new antibiotic drugs to treat infectious diseases caused by pathogenic and drug resistant strains and can also be analyzed if this strain has any PGPR or weed biocontrol activity.

\section{ACKNOWLEDGMENT}

The financial support received from the UGC-SAPDSA-1, Department of Botany, Karnatak University, Dharwad, 
Karnataka, India, was gratefully acknowledged. The authors also thank USIC, Karnatak University, Dharwad for necessary instrument facility.

\section{CONFLICTS OF INTEREST}

Authors declare that there are no conflicts of interest.

\section{REFERENCES}

Bafana A, Lohiya R. Diversity and metabolic potential of culturable root-associated bacteria from Origanum vulgare in subHimalayan region. World J Microbiol Biotechnol, 2013; 29:63-74.

Dai L, Huancheng P, Licui S, Jinping F, Yuyi L, Jianli Z. Pseudoxanthomonas wuyuanensis sp. nov., isolated from saline-alkali soil. Int J Syst and Evol Microbiol, 2014; 64:799-804.

Fatima MS, Aruna SS, Anbumalarmathi J, Umamaheswari $\mathrm{K}$. Isolation, molecular characterization and identification of antibiotic producing actinomycetes from soil samples. J Appl Pharm Sci, 2017 7(9):69-75.

Finkmann W, Altendorf K, Stackebrandt E, Lipski A. Characterization of N2O-producing Xanthomonas-like isolates from biofilters as Stenotrophomonas nitritireducens sp. nov., Luteimonas mephitis gen. nov., sp. nov. andPseudoxanthomonas broegbernensis gen. nov., sp. nov. Int J Syst Evol Microbiol, 2000; 50:273-82. London, 1984.

Hooker JD. The flora of British India. The Muston Company,

Kaestli M, Schmid M, Mayo M, Michael R, Glenda H, Leisha R, Audrey H, Jason H, Apichai T, Paul K, Anton H, Bart JC. Out of the ground: aerial and exotic habitats of the melioidosis bacterium Burkholderia pseudomallei in grasses in Australia. Environ Microbiol, 2011; 14:2058-70.

Kemp W. Energy and electromagnetic spectrum. In: Kemp W (ed.). Organic spectroscopy, Macmillan Press, London, UK, pp 1-7, 1991a.

Kemp W. Infrared spectroscopy. In: Kemp W (ed.). Organic spectroscopy, Macmillan Press Ltd., London, UK, pp 19-56, 1991 b.

Kent AD, Triplett EW. Microbial communities and their interactions insoil and rhizosphere ecosystems. Annu Rev Microbiol, 2002; 56:211-36.

Kumar S, Stecher G, Tamura K. MEGA 7: molecular evolutionary genetics analysis version 7.0 for bigger data sets. Mol Biol Evol, 2016; 33(7):1870-4

Lee $\mathrm{JH}$, Lee J. Indole as an intercellular signal in microbial communities. FEMS Microbiol Rev, 2010; 34(4):426-44.

Mangathayaru K, Lakshmikant J, Shyam SN, Swapna R, Grace $\mathrm{XF}$, Vasantha J. Antimicrobial activity of Leucas aspera flowers. Fitaterapia, 2005; 76(7-8):752-4.

Merckx R, Dijkstra A, Hartog AD, Veen JAV. Production of rootderived material and associated microbial growth in soil at different nutrient levels. Biol Fertil Soils, 1987; 5:126-32.

Mohapatra B, Sar P, Kazy SK, Maiti MK, Satyanarayana T. Taxonomy and physiology of Pseudoxanthomonas arseniciresistens sp. nov., an arsenate and nitrate-reducing novel gammaproteobacterium from arsenic contaminated groundwater, India. Plos One, 2018; 13(3):e0193718.
Rai V, Agarwal M, Agnihotri AK, Khatoon S, Rawat AK, Mehrotra S. Pharmacognostical evaluation of Leucas aspera. Nat Prod Sci, $2005 ; 11: 109-14$.

Rayees S, Kumar A, Rasool S, Kaiser P, Satti NK, Sangwan PL, Singh S, Johri RK, Singh G. Ethanolic extract of Alternanthera sessilis (AS-1) inhibits IgE-mediated allergic response in RBL-2H3 cells. Immunol Invest, 2013; 42(6):470-80.

Saravanakumar P, Duraipandiyan V, Ignacimuthu S. Isolation, screening and partial purification of antimicrobial antibiotics from soil Streptomyces sp. SCA 7. Kaohsiung J Med Sci, 2014; 30(9):435-46.

Soo-JK, Jae-HA, Hang YW, Jun ML, Song GK, Soon WK. Pseudoxanthomonas sangjuensis sp. nov., isolated from greenhouse soil. Int J Syst Evol Microbiol, 2015; 65:3170-4.

Teplitski M, Warriner K, Bartz J, Schneider KR. Untangling metabolic and communication networks: interactions of enterics with phytobacteria and their implications in produce safety. Trends Microbiol, 2011; 19:121-7.

Thierry S, Macarie H, Iizuka T, GeiBdorfe W, Assih EA, Spanevello M, Verhe F, Thomas P, Fudou R, Monroy O, Labat M, Aboubakar SO. Pseudoxanthomonas Mexicana sp. nov. and Pseudoxanthomonas japonensis sp. nov., isolated from diverse environments, and emended descriptions of the genus Pseudoxanthomonas Finkmann et al., 2000 and of its type species. Int J Syst Evol Microbiol, 2004; 54(6):2245-55.

Ullah MO, Haque M, Urmi KF, Zulfiker AH, Anita ES, Begum M, Hamid K. Anti-bacterial activity and brine shrimp lethality bioassay of methanolic extracts of fourteen different edible vegetables from Bangladesh. Asian Pac J Trop Biomed, 2013; 3(1):1-7.

Weon HY, Kim BY, Kim JS, Lee SY, Cho YH, Go SJ, Hong B, Im WT, Kwon SW. Pseudoxanthomonas suwonensis sp. nov., isolated from cotton waste composts. Int J Syst Evol Microbiol, 2006; 56(3):659-62.

Yoo SH, Weon HY, Kim BY, Kim JH, Baek YK, Kwon SW, Go SJ, Stackebrandt E. Pseudoxanthomonas yeongjuensis sp. nov., isolated from soil cultivated with Korean ginseng. Int J Syst Evol Microbiol, 2007; 57:646-49.

Yoon JH, Lee ST, Park YH. Inter- and intraspecific phylogenetic analysis of the genus Nocardioides and related taxa based on 16S rDNA sequences. Int J Syst Bacteriol, 1998; 48:187-94.

Zakaria MS, Anawar HM. Rhizosphere microbes interactions in medicinal plants. Soil Biol, 201; 42:19-41.

How to cite this article:

Sreenivasa N, Bidhayak C, Pallavi SS, Meghashyama PB, Dattatraya A, Dhanyakumara SB, Muthuraj R, Halaswamy $\mathrm{H}$, Shashiraj KN, Chaitra M. Isolation, characterization, and functional group analysis of Pseudoxanthomonas indica RSA-23 from rhizosphere soil. J Appl Pharm Sci, 2019; 9(11):101-106. 